\title{
PEMERIKSAAN KENDARAAN BERMOTOR DI KABUPATEN SUMENEP MENURUT HUKUM POSITIF
}

\author{
ABSHORIL FITHRY \\ Fakultas Hukum, Universitas Wiraraja Sumenep \\ abshorilfithry@ rocketmail.com \\ MOH. ANWAR \\ Dosen Fakultas Hukum Universitas Wiraraja Sumenep \\ Mohanwar752@yahoo.com
}

\begin{abstract}
ABSTRAK
Razia, adalah momok bagi para pengguna jalan baik sepeda motor maupun mobil. Tidak dapat dipungkiri juga bahwa banyak sekali para pengguna kendaraan yang takut ketika melihat adanya operasi yang dilakukan oleh Satuan Lalu Lintas (Satlantas). Bahkan banyak sekali terlihat ketika diadakan operasi di jalan, banyak para pengguna kendaraan terutama kendaraan roda dua yang langsung berbalik arah. Hal ini bisa saja menjadi salah satu penyebab terjadinya kecelakaan lalu lintas. Banyak kejadian yang terjadi di Kabupaten Sumenep ketika para anggota Kepolisian Lalu Lintas sedang melakukan Razia atau Operasi Kendaraan Bermotor tidak memperdulikan apa yang sudah diamanatkan dalam Peraturan Pemerintah Nomor 42 Tahun 1993 yaitu pasal 13-14 serta Peraturan Pemerintah Nomor 80 Tahun 2012 pasal 15 (ayat) 1-3, yang mengharuskan ada tanda razia seperti plang pemeriksaan yang seharusnya dipasang $100 \mathrm{~m}$ sebelum lokasi razia, prosedur pemeriksaan kendaraan bermotor (RAZIA) yang dilakukan di jalan oleh Polantas menurut hukum positif dilakukan dengan menelaah seluruh peraturan perundang-undangan yang sekiranya berkaitan dengan judul yang kami angkat diantaranya adalah undang-undang Nomor 22 Tahun 2009 tentang lalu lintas dan angkutan jalan, Peraturan Pemerintah Nomor 42 Tahun 1993 tentang pemeriksaan kendaraan bermotor di jalan, Peraturan Pemerintah Nomor 80 Tahun 2012 tentang Tata cara pemeriksaan kendaraan bermotor di jalan dan penindakan pelanggaran lalu lintas dan angkutan jalan.
\end{abstract}

Kata kunci : Pemeriksaan Kendaraan Bermotor.

\section{A. PENDAHULUAN}

Razia, adalah momok bagi para pengguna jalan baik sepeda motor maupun mobil. Tidak dapat dipungkiri juga bahwa banyak sekali para pengguna kendaraan yang takut ketika melihat adanya operasi yang dilakukan oleh Satuan Lalu Lintas (Satlantas). Bahkan banyak sekali terlihat ketika diadakan operasi di jalan, banyak para pengguna kendaraan terutama kendaraan roda dua yang langsung berbalik arah. Hal ini bisa saja menjadi salah satu penyebab terjadinya kecelakaan lalu lintas.

Perlu diketahui bersama bahwa sebenarnya razia yang dilakukan sebenarnya untuk kepentingan bersama, yaitu bertujuan menciptakan situasi yang nyaman ketika berkendara. Pemeriksaan surat-surat misalnya diperuntukkan untuk mengetahui apakah pengendara tersebut sudah layak atau cukup umur untuk mengendarai kendaraannya. Karena apabila tidak memiliki Surat Izin Mengemudi (SIM) artinya orang tersebut 
belum memenuhi salah satu persyaratan administrasi yaitu kategori umur yang artinya belum dewasa, karena belum dewasa itulah banyak sekali terjadi kecelakaan yang disebabkan tidak tahunya pada rambu-rambu lalu lintas. Kadang meskipun sudah cukup umur, belum mempunyai SIM dikarenakan tidak lolos tes tulis ataupun praktek. Tes tulis maupun tes praktek dibuat untuk mengetahui sejauh mana para pengendara kendaraan bermotor bisa tahu dan memahami ramburambu lalu lintas yang serta kemampuan berkendara orang tersebut.

Pemeriksaan surat-surat yang lain seperti Surat Tanda Kendaraan Bermotor (STNK) dilakukan agar dapat dengan mudah diketahui apakah kendaraan tersebut kendaraan bodong atau tidak. Bahkan kadang-kadang polisi lalu lintas (POLANTAS) melakukan razia tidak hanya pada waktu-waktu tertentu tapi kadang juga melakukan razia ketika dapat laporan ada kejahatan di jalan.

Razia yang dilakukan oleh polantas itu sendiri terkadang dilakukan di tempat-tempat yang kadang masyarakat tidak bisa menduganya. Bahkan banyak paradigma dalam masyarakat Sumenep mengatakan bahwa razia yang dilakukan cenderung di tempat-tempat yang bisa menjebak para pengendaranya, sehingga ketika masyarakat tahu atau sadar ada razia sudah tidak bisa berbalik arah bahkan kalau mau berbalik arahpun biasanya langsung berbalik arah karena kaget, hal seperti ini merupakan salah satu penyebab terjadinya kecelakaan lalu lintas.

Perlu diketahui bersama bahwa sebenarnya tata cara POLANTAS melakukan razia sudah tertuang baik di dalam Undangundang Nomor 22 Tahun 2009 tentang Lalu lintas dan angkutan jalan, Peraturan Pemerintah Nomor 80 Tahun 2012 tentang Tata cara pemeriksaan kendaraan bermotor di jalan dan penindakan pelanggaran lalu lintas dan angkutan jalan, Peraturan Pemerintah Nomor 42 Tahun 1993 tentang Pemeriksaan kendaraan bermotor di jalan, serta peraturan peraturan yang lainnya yang nanti akan dikupas lebih lanjut.

Banyak kejadian yang terjadi di Kabupaten Sumenep ketika para anggota Kepolisian Lalu Lintas sedang melakukan Razia atau Operasi Kendaraan Bermotor tidak memperdulikan apa yang sudah diamanatkan dalam Peraturan Pemerintah Nomor 42 Tahun 1993 yaitu pasal 13-14 serta Peraturan Pemerintah Nomor 80 Tahun 2012 pasal 15 (ayat) 1-3, yang mengharuskan ada tanda razia seperti plang pemeriksaan yang seharusnya dipasang $100 \mathrm{~m}$ sebelum lokasi razia.

\section{B. PEMBAHASAN}

Kewenangan Petugas kepolisian dalam melakukan pemeriksaan di atur di dalam Undang-undang. Dimulai dari tata cara bahkan prosedur pemeriksaan. Hal ini tertuang di dalam pasal 15 Peraturan Pemerintah Nomor 80 Tahun 2012 Tentang 
Tata Cara Pemeriksaan Kendaraan Bermotor di Jalan dan Penindakan Pelanggaran Lalu lintas dan Angkutan Jalan.

Petugas Kepolisian Republik Indonesia atau Penyidik Pegawai Pegawai Negri Sipil di Bidang Lalu Lintas dan Angkutan Jalan yang melakukan pemerikasaan kendaraan Bermotor di Jalan secara berkala atau Insidental atas dasar operasi kepolisian dan/atau penanggulangan kejahatan wajib dilengkapi dengan surat perintah tugas.

Surat perintah tugas sebagaimana dimaksud pada ayat (1) dikeluarkan oleh:

a. Atasan petugas Kepolisian Negara Republik Indonesia bagi petugas Kepolisian Negara Republik Indonesia; dan

b. Atasan penyidik Pegawai Negeri Sipil di bidang Lalu Lintas dan Angkutan Jalan bagi Penyidik Pegawai Negeri Sipil di Bidang lalu lintas dan Angkutan Jalan.

Surat perintah tugas sebagaimana dimaksud pada ayat (2) paling sedikit memuat Alasan dan pola pemeriksaan kendaraan bermotor, Waktu pemeriksaan kendaraan bermotor, Tempat pemeriksaan kendaraan bermotor, Penanggung Jawab dalam pemeriksaan kendaraan bermotor serta Daftar petugas Kepolisian Negara Republik Indonesia dan/atau Penyidik Pegawai Negeri Sipil di bidang lalu lintas dan Angkutan Jalan yang di tugaskan melakukan pemeriksaan Kendaraan Bermotor.

Selain itu kewenangan polisi untuk melakukan pemeriksaan surat-surat kendaraan tertuang juga di dalam pasal 265 Undangundang Nomor 22 Tahun 2009 tentang lalu lintas dan Angkutan Jalan yang berbunyi : Pemeriksaan Kendaraan Bermotor di Jalan sebagaimana dimaksud dalam pasal 264 meliputi pemeriksaan :

a. Surat Izin Mengemudi, Surat Tanda Nomor Kendaraan Bermotor, Surat Tanda Coba Kendaraan Bermotor, Tanda Nomor Kendaraan bermotor atau Tanda Coba Kendaraan Bermotor.

b. Tanda bukti lulus uji bagi kendaraan wajib uji

c. Fisik Kendaraan Bermotor.

d. Daya angkut dan/atau cara pengangkutan barang dan; atau

e. Izin penyelenggaraan angkutan

Pemeriksaan Kendaraan Bermotor di jalan sebagaimana dimaksud pada ayat (1) dapat dilakukan secara berkala atau Insidental sesuai dengan kebutuhan.

Untuk melaksanakan pemeriksaan kendaraan bermotor sebagaimana dimaksud pada ayat (1), petugas Kepolisian Negara Republik Indonesia berwenang untuk:

a. menghentikan Kendaraan bermotor

b. meminta keterangan kepada pengemudi dan atau

c. melakukan tindakan lain menurut hukum secara bertanggung jawab.

Di Sumenep terdapat beberapa pelanggaran yang sering dilakukan oleh Para Oknum Polantas yang dengan seenaknya sendiri melakukan Razia, hal ini dilakukan tentu saja menyalahi aturan perundang- 
undangan yang ada seperti : Tidak ada plang pemeriksaan yang diletakkan 100 Meter sebelum Razia. Bahkan biasanya dilakukan pada tempat-tempat tertentu seperti Dijalan lingkar barat, biasanya kalau di daerah ini terjadi pada pukul 9.30 pagi, dan biasanya juga hanya dua orang yang menjaga. Daerah berikutnya adalah Daramista, bisanya razia yang dilakukan di daerah ini setiap hari minggu siang, tempat berikutnya juga di kebunagung tepatnya di kantor Komisi Pemilihan Umum (KPU), kapan terjadinya? Biasanya ini terjadi ketika pas lagi pengamanan di kantor KPU, banyak kendaraan yang diberhentikan dan ditilang. Ketiga tempat tadi merupakan tiga daerah tersering, yang paling sering dilakukan razia tanpa ada plang pemeriksaan.

Hal ini akan berdampak pada masyarakat yang notabene belum mengerti tentang hukum. Banyak para pengguna kendaraan bermotor langsung berbelok arah ketika melihat ada pemeriksaan kendaraan bermotor. Bagaimana seandainya ketika ada pemeriksaan yang tidak menggunakan plang pemeriksaan tiba-tiba ada kendaraan bermotor yang langsung berbalik arah kemudian terjadi kecelakaan? Siapa yang akan bertanggung jawab?

Aparat seharusnya memberi contoh yang baik kepada masyarakat, kalau pengguna kendaraan bermotor ditilang gara-gara melanggar salah satu ketentuan di Undangundang Nomor 22 tahun 2009 tentang lalu lintas, bagaimana kalau polantas yang melanggar ketentuan undang-undang Nomor 22 Tahun 2009 tentang lalu lintas dan angkutan jalan, Peraturan Pemerintah Nomor 42 Tahun 1993 tentang pemeriksaan kendaraan bermotor di jalan, Pasal 5, Pasal 6 ayat (1) huruf a, dan Pasal 7 ayat (1) huruf c dan huruf e UU No. 8 tahun 1981 Tentang Hukum Acara Pidana (KUHAP), Pasal 16 UU No. 2 tahun 2002 Tentang Kepolisian Negara Republik Indonesia, Peraturan Pemerintah Nomor 80 Tahun 2012 Tentang Tata Cara Pemeriksaan Kendaraan Bermotor Di Jalan Dan Angkutan Jalan jo Pasal 260 UU No. 22 Tahun 2009 Tentang Lalu Lintas Dan Angkutan Jalan. Pasal 104 UU No. 8 Tahun 1981 Tentang KUHAP: Pasal 5, Pasal 6 ayat (1) huruf a, dan Pasal 7 ayat (1) huruf $c$ dan huruf e UU No. 8 tahun 1981 Tentang Hukum Acara Pidana (KUHAP), Pasal 16 UU No. 2 tahun 2002 Tentang Kepolisian Negara Republik Indonesia? Bukankah hal tersebut lebih parah dari pada pelanggaran yang dilakukan oleh Oknum tersebut?

Hal seperti ini harus segera di tindak lanjuti oleh para stake holder dalam hal ini Provos yang bertugas menyidik oknum polisi yang nakal, sehingga masyarakat atau para pengguna kendaraan bermotor tidak dirugikan, artinya jangan hanya masyakat saja yang disuruh taat pada aturan sedangkan aparat yang melanggar dibiarkan begitu saja.

Kita sebagai warga Negara Indonesia yang baik memang berhak menanyakan surat tugas ataupun surat perintah kepada petugas, hal ini bertujuan untuk mengetahui apakah 
razia yang dilakukan oleh polantas resmi atau tidak. Dan surat perintah tersebut merupakan kewajiban yang harus diperhatikan oleh polantas, hal ini tertuang didalam pasal 15 Peraturan Pemerintah Nomor 80 Tahun 2012 Tentang Tata Cara Pemeriksaan Kendaraan Bermotor di Jalan dan Penindakan Pelanggaran Lalu lintas dan Angkutan Jalan.

Hal ini perlu di luruskan bahwa antara Razia dan tertangkap langsung karena terlebih dahulu melakukan pelanggaran merupakan dua jenis penindakan yang berbeda, kalau Razia harus sesuai ketentuan undang-undang Nomor 22 Tahun 2009 tentang lalu lintas dan angkutan jalan, Peraturan Pemerintah Nomor 42 Tahun 1993 tentang pemeriksaan kendaraan bermotor di jalan, Pasal 5, Pasal 6 ayat (1) huruf a, dan Pasal 7 ayat (1) huruf c dan huruf e UU No. 8 tahun 1981 Tentang Hukum Acara Pidana (KUHAP), Pasal 16 UU No. 2 tahun 2002 Tentang Kepolisian Negara Republik Indonesia, Peraturan Pemerintah Nomor 80 Tahun 2012 Tentang Tata Cara Pemeriksaan Kendaraan Bermotor Di Jalan Dan Angkutan Jalan jo Pasal 260 UU No. 22 Tahun 2009 Tentang Lalu Lintas Dan Angkutan Jalan. Pasal 104 UU No. 8 Tahun 1981 Tentang KUHAP: Pasal 5, Pasal 6 ayat (1) huruf a, dan Pasal 7 ayat (1) huruf c dan huruf e UU No. 8 tahun 1981 Tentang Hukum Acara Pidana (KUHAP), Pasal 16 UU No. 2 tahun 2002 Tentang Kepolisian Negara Republik Indonesia.

Harus dibedakan juga mana yang "berkala", mana yang Insidental. Yang dimaksud dengan berkala didalam pasal 265 Undang-undang Nomor 22 tahun 2009 adalah pemeriksaan yang dilakukan secara bersamasama demi efisiensi dan efektifitas agar tidak terjadi pemeriksaan yang berulang-ulanng dan merugikan masyarakat, sedangkan "incidental" adalah tindakan petugas terhadap pelanggaran yang tertangkap tangan, pelaksanaan operasi kepolisian dengan sasaran keamanan, keselamatan, ketertiban, dan kelancaran lalu lintas dan angkutan jalan serta penanggulangan kejahatan.

Jadi apabila ada pelanggaran yang tertangkap tangan maka tidak usah menggunakan surat perintah lagi, karena itu berhubungan dengan efisiensi dan efektifitas. Kalau masih menunggu surat perintah maka si pelanggar bisa kabur duluan.

\section{KESIMPULAN}

Di Sumenep terdapat beberapa pelanggaran yang sering dilakukan oleh Para Oknum Polantas yang dengan seenaknya sendiri melakukan Razia, hal ini dilakukan tentu saja menyalahi aturan perundangundangan yang ada seperti : Tidak ada plang pemeriksaan yang diletakkan 100 Meter sebelum Razia. Bahkan biasanya dilakukan pada tempat-tempat tertentu seperti Dijalan lingkar barat, biasanya kalau di daerah ini terjadi pada pukul 9.30 pagi, dan biasanya juga hanya dua orang yang menjaga. Daerah berikutnya adalah Daramista, bisanya razia yang dilakukan di daerah ini setiap hari minggu siang, tempat berikutnya juga di 
kebunagung tepatnya di kantor Komisi

Pemilihan Umum (KPU), kapan terjadinya?

Biasanya ini terjadi ketika pas lagi pengamanan di kantor KPU, banyak kendaraan yang diberhentikan dan ditilang. Ketiga tempat tadi merupakan tiga daerah tersering, yang paling sering dilakukan razia tanpa ada plang pemeriksaan.

\section{DAFTAR BACAAN}

C.S.T. Kansil, 1995, Disiplin Berlalu Lintas di Jalan, Cet. 1, PT Rineka Cipta, Jakarta.

Suwardjoko P. Warpani, 2002, Pengelolaan Lalu lintas dan Angkutan Jalan, ITB.

Sugiono, 2012, Metode Penelitian Kuantitatif, Kualitatif dan $R \& D$, Cet. 16, Penerbit Alfabeta, Bandung.
Peter Mahmud Marsuki, 2005, Penelitian Hukum, Cet 1, Persada Media, Jakarta.

Undang-undang Republik Indonesia Nomor 22 Tahun 2009 tentang Lalu lintas dan Angkutan Jalan, Cet 1, Citra Umbara, Bandung.

Peraturan Pemerintah Nomor 55 Tahun 2012 tentang Kendaraan.

Peraturan Pemerintah Nomor 42 Tahun 1993 tentang pemeriksaan kendaraan bermotor di jalan.

Peraturan Pemerintah Nomor 80 Tahun 2012 Tentang Tata Cara Pemeriksaan Kendaraan Bermotor Di Jalan Dan Angkutan Jalan. 